\title{
Revitalisasi Stasiun Kereta Api Kedundang Di Kulon \\ Progo \\ (Penekanan Desain Pada Pola Sirkulasi Dan Tata Ruang)
}

\author{
Rodrigues Francisco Lopes de Carvalho'), Yuni Triastuti, Padmana \\ Grady Prabasmara
}

\begin{abstract}
ABSTRAK
Stasiun Kereta Api Kedundang adalah stasiun kereta api kelas kecil yang berfungsi sebagai tempat persilangan kereta api yang dinonaktifkan sejak tahun 2007. Kondisi saat ini mengalami banyak kerusakan akibat tidak terawat sejak penonaktifan tersebut. Stasiun Kereta Api Kedundang, dewasa ini, direncanakan menjadi sebuah stasiun kereta api yang berfungsi sebagai simpul penghubung dalam rute transportasi kereta api bandara yang menghubungkan Bandara NYIA (New Yogyakarta International Airport) di Kulon Progo dengan Kota Yogyakarta. Rencana ini dapat diwujudkan dengan merevitalisasi dan meningkatkan kelas Stasiun Kereta Api Kedundang menjadi kelas sedang agar sesuai dengan fungsi baru yang direncanakan. Revitalisasi dilakukan untuk menghidupkan kembali Stasiun Kereta Api Kedundang dengan penyesuaian terhadap fungsi baru yang terintegrasi dengan Bandara NYIA. Peningkatan kelas mengacu pada Pedoman Standardisasi Stasiun Kereta Api Indonesia Tahun 2012. Konsep revitalisasi selanjutnya digunakan sebagai landasan dalam tahap perancangan arsitektur yang menitikberatkan pada dua aspek yaitu pola sirkulasi dan tata ruang. Penekanan desain pada kedua aspek ini guna menjamin keselamatan, keamanan, kenyamanan dan kelancaran bagi penumpang kereta api. Hasil perancangan merupakan alternatif solusi desain, untuk menjawab permasalahan-permasalahan Stasiun Kereta Api Kedundang.
\end{abstract}

Kata Kunci: Stasiun Kereta Api Kedundang, Revitalisasi, Pola Sirkulasi dan Tata Ruang.

\section{Bahan dan Metode Pembahasan}

Bandara Kulon Progo atau
NYIA (New Yogyakarta
Internasional Airport) sebagai
pusat kawasan strategis bandar
udara perlu didukung oleh sistem
transportasi yang memadai.
Pemerintah
mengembangkan infrastruktur-
infrastruktur transportasi darat,
salah satunya di sub sektor
transportasi kereta api sebagai
dukungan konektivitas utama
Bandara Kulon Progo terutama
dengan Kota Yogyakarta.
Efektivitas dan efisiensi moda
kereta api dinilai mampu
mengatasi persoalan jarak tempuh

antara Bandara Kulon Progo dengan Kota Yogyakarta. Pengembangan di sub sektor transportasi kereta api meliputi pembangunan jalur rel 
kereta api bandara serta reaktivasi Stasiun Kereta Api Kedundang. Alasan dipilihnya Stasiun Kereta Api Kedundang dikarenakan merupakan stasiun kereta api yang paling dekat dengan Bandara Kulon Progo.

Kondisi bangunan dan fasilitas pendukungnya rusak akibat tidak terawat sejak dinonaktifkan. Kondisi demikian menjadi kendala dalam mereaktivasi stasiun kereta api ini untuk mendukung operasional Bandara Kulon Progo. Hal ini membuat pemerintah berencana merevitalisasi dengan meningkatkan kelasnya menjadi kelas sedang guna menyesuaikan terhadap kapasitas Bandara Kulon Progo dan proyeksi peningkatan jumlah penumpang kereta api setiap tahunnya. Revitalisasi merupakan solusi yang paling tepat untuk menjadikannya sebagai stasiun kereta api penghubung Bandara Kulon Progo dengan Kota Yogyakarta.

Stasiun Kereta Api Kedundang sebagai stasiun kereta api intermoda, harus memiliki fasilitas-fasilitas untuk mewadahi berbagai jenis dan jumlah pengguna yang banyak dengan kepentingan dan tujuan perjalanan yang berbeda. Proses desain yang merupakan bagian penting dari revitalisasi ini menitikberatkan pada 2 (dua) aspek yaitu pola sirkulasi dan tata ruang. Penekanan pada kedua aspek ini guna menjamin keselamatan, keamanan dan kelancaran bagi penumpang kereta api.

Pola sirkulasi dan tata ruang perlu direncanakan dengan baik agar ruangruang di dalam dan di luar stasiun dapat dimanfaatkan secara optimal. Pola sirkulasi dan tata ruang yang sinkron dapat memberikan kenyamanan dan kesempatan yang optimal bagi penumpang maupun pengelola untuk melakukan berbagai kegiatan.

\section{Bahan dan Metode Pembahasan}

Metode yang digunakan penulis untuk mengumpulkan data yang dibutuhkan dalam penelitian ini adalah metode observasi, studi pustaka dan dokumen. Observasi bertujuan untuk mengamati secara langsung dan sistematis terhadap kondisi Stasiun Kereta Api Kedundang. Studi pustaka digunakan untuk mengumpulkan data-data dari literatur berupa data-data yang tidak bisa diperoleh langsung melalui studi lapangan selama periode waktu penelitian. Studi dokumen berupa data melalui dokumen tertulis maupun elektronik dari lembaga yang diperlukan untuk mendukung kelengkapan data yang lain.

Metode pembahasan yang digunakan di antaranya, metode analisis deskriptif kualitatif, studi komparatif, dan metode kuantitatif. Metode analisis deskriptif kualitatif bertujuan untuk menguraikan data dan karakteristik obyek penelitian yang telah diolah dan disajikan dalam bentuk tabel dan grafik analisis. Metode analisis studi komparatif digunakan untuk membandingkan prinsip-prinsip desain obyek preseden berupa stasiun kereta api yang sekelas/ setipe/ mirip dengan Stasiun Kereta Api Kedundang untuk mendapatkan prinsip-prinsip desain yang baru. Metode kuantitatif dalam penelitian ini untuk menganalisis data-data berupa 
angka-angka dalam format terstruktur dalam analisis besaran ruang Stasiun Kereta Api Kedundang.

\section{Tujuan}

Tujuan dari penelitian ini ialah mengungkapkan permasalahanpermasalahan dalam revitalisasi Stasiun Kereta Api Kedundang serta memberikan alternatif pemecahannya secara arsitektural sebagai konsep revitalisasi.

\section{Hasil dan Pembahasan}

Fasilitas Existing di dalam tapak berupa Bangunan Stasiun, Ruang Sintelis dan dua unit Rumah DKA (Dinas Kereta Api) dimanfaatkan kembali dengan fungsi ruang baru. Hal ini dikarenakan bangunan-bangunan tersebut kondisi fisiknya masih layak untuk digunakan kembali dan sesuai dengan konsep revitalisasi yang berkaitan dengan alur kegiatan penumpang, mulai dari proses awal kedatangan hingga keberangkatan.

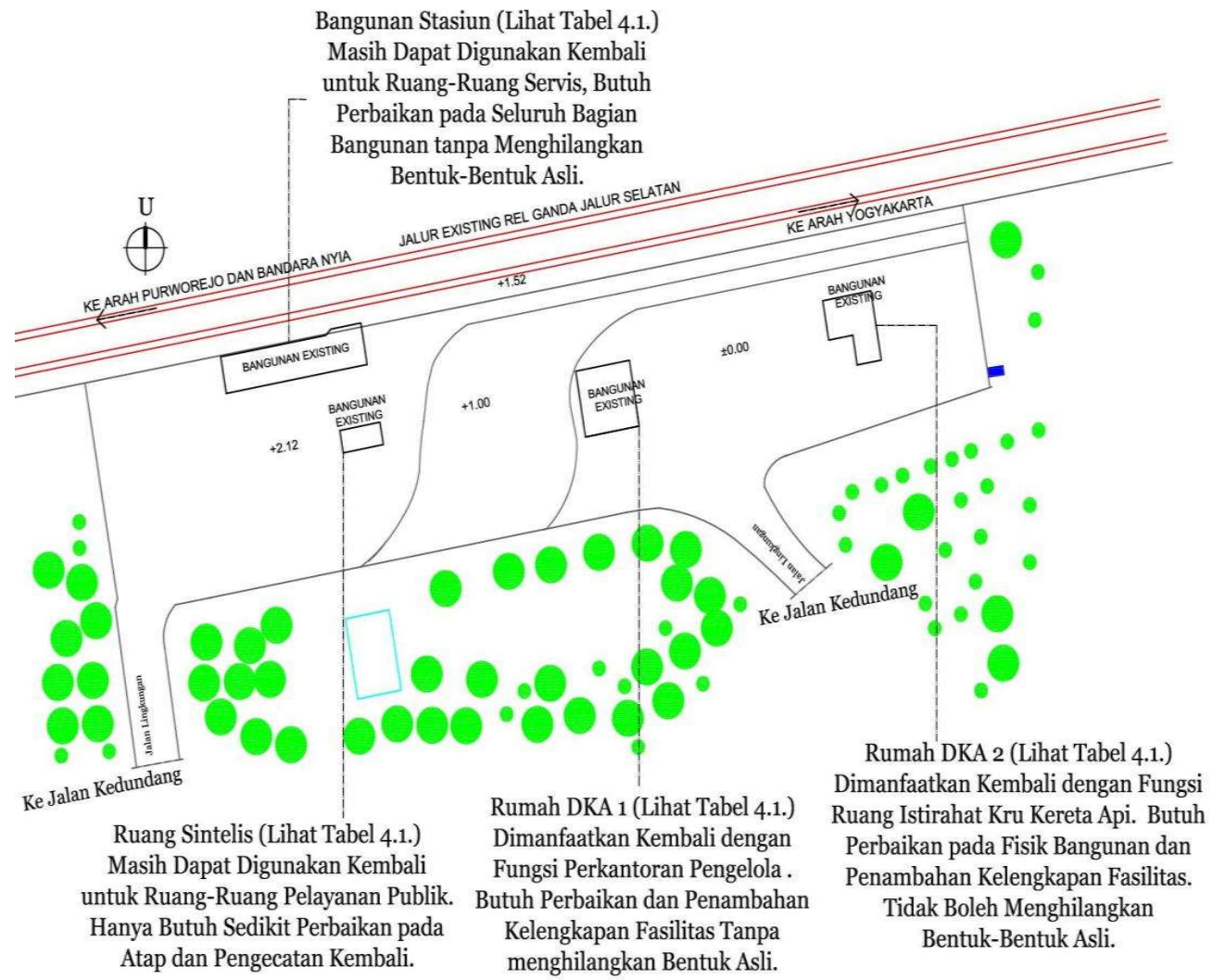

Gambar 1. Pemanfaatan Bangunan Existing 
a. Sirkulasi Pencapaian

Konsep sirkulasi pencapaian berdasarkan pertimbangan sirkulasi yang mudah, jelas dan aman bagi pejalan kaki maupun kendaraan dengan prinsip menghindari perpotongan antar alur sirkulasi.
Pencapaian dibedakan menurut pelaku dan kegiatannya dikelompokkan menjadi pencapaian pengelola dan pengunjung (penumpang, calon penumpang serta pengantar dan penjemput).

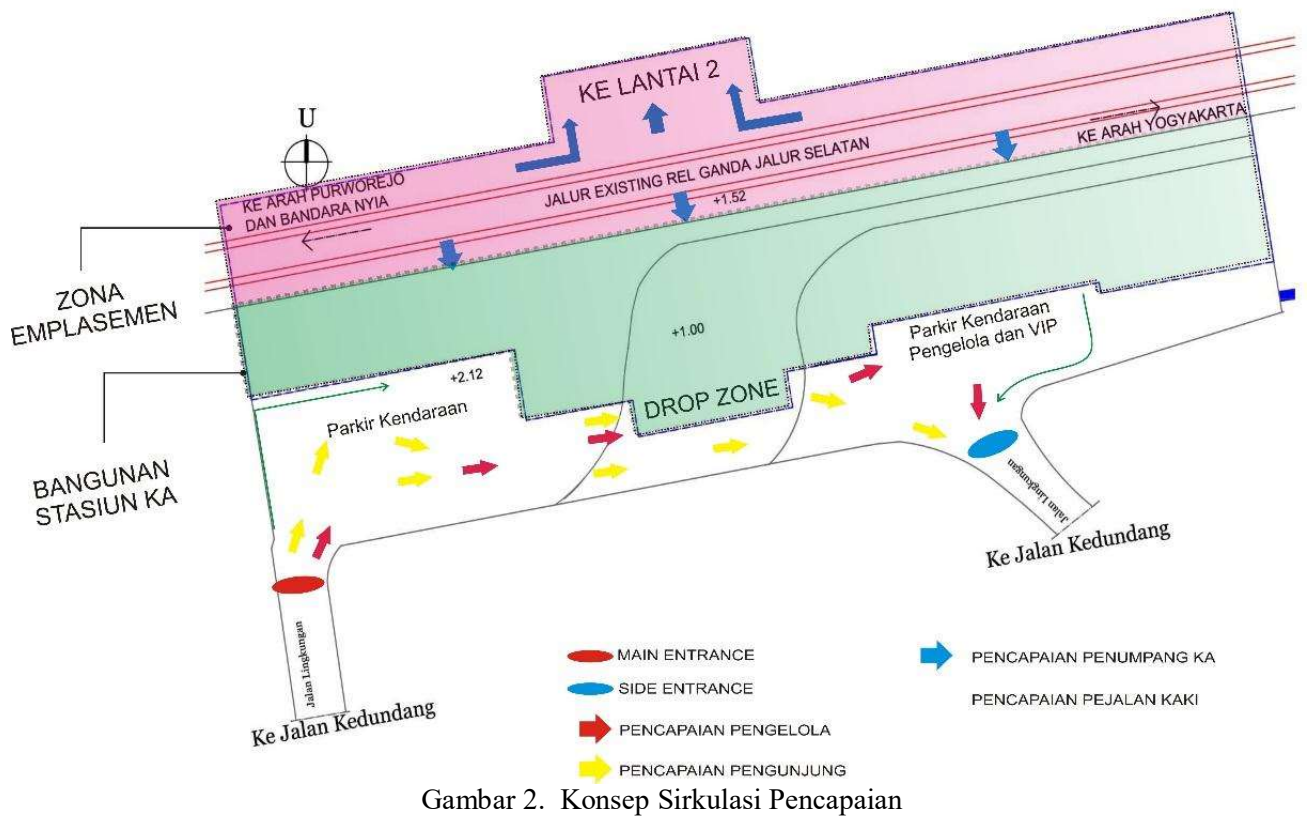

Konsep persyaratan sirkulasi pencapaian, adalah sebagai berikut:

- Entrance kendaraan dipisah berdasarkan jenis dan besar massanya;

- Alur keluar masuk kendaraan dipisah;

- Pemisahan antara jalur kendaraan dan pejalan kaki;

- Sirkulasi pencapaian kendaraan maupun pejalan kaki dalam tapak menggunakan pola tidak langsung; dan

- Pintu masuk ke bangunan menggunakan pola menjorok keluar untuk menunjukkan fungsinya sebagai tujuan pencapaian dan menaungi kedatangan pengunjung pada drop zone.

b. Orientasi Bangunan

$$
\begin{aligned}
& \text { Pertimbangan } \\
& \text { dalam analisis arah } \\
& \text { hadap bangunan } \\
& \text { ini di antaranya; }
\end{aligned}
$$

- Arah view terbaik pengguna ke arah bangunan;

- Pola perjalanan kereta api jalur Bandara Kulon Progo Stasiun Kereta Api

Kedundang - Stasiun Tugu

Yogykarta; 
- Sirkulasi pencapaian pengguna; dan

- Bangunan di sekitar tapak.

Pertimbangan-pertimbangan di atas, maka didapatkan orientasi bangunan ke arah timur dan barat, ke arah datang dan pergi kereta api sedangkan orientasi bangunan ke selatan untuk view atau arah datang pengguna dari luar tapak.

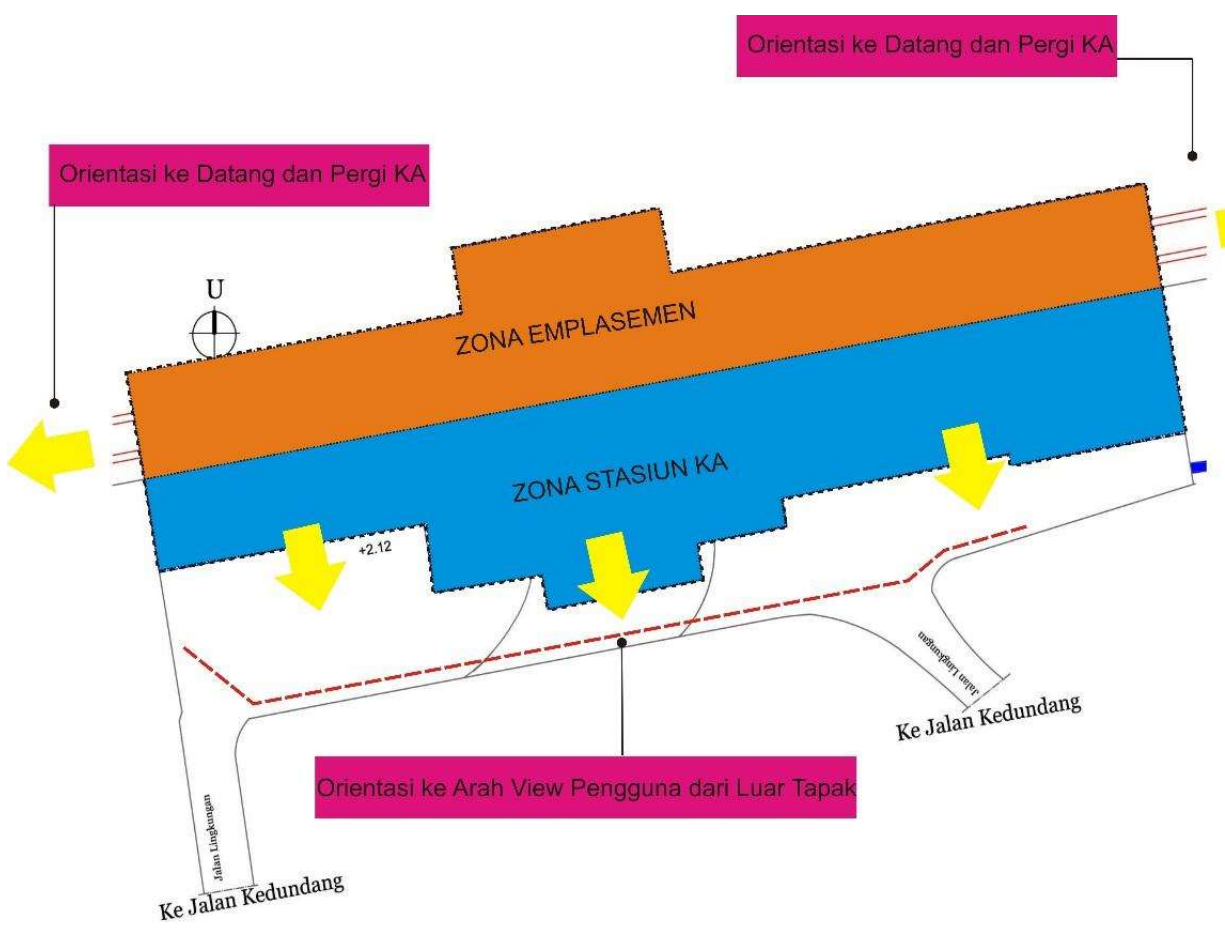

Gambar 3. Orientasi Bangunan

c. Pelaku Kegiatan dan Kebutuhan Ruang

Pelaku di stasiun kereta api sedang dikelompokkan menurut pedoman standarisasi stasiun kereta api tahun 2012, ada empat kategori, di antaranya:

- Penumpang merupakan pengguna jasa angkutan kereta api di stasiun kereta api.

Penumpang terbagi menjadi dua, meliputi:

- Penumpang naik (calon penumpang kereta api); dan

- Penumpang turun (eks penumpang kereta api).

- Pengelola stasiun kereta api kelas sedang, terdiri dari;

- Petugas Operasional, meliputi:

$\checkmark$ Kepala Stasiun

$\checkmark \quad$ Wakil Kepala Stasiun

$\checkmark$ Petugas Keuangan

$\checkmark$ Petugas Peralatan $\checkmark \quad$ Kru UPT KA

$\checkmark$ Petugas PPKA

$\checkmark$ Petugas Keamanan

$\checkmark$ Petugas Kebersihan 


\section{$\checkmark$ Petugas Bagian Utilitas $\quad \checkmark \quad$ Petugas Pantry}

$\checkmark$ Petugas Administrasi

- Ruang pelayanan dan publik, meliputi:

$\checkmark$ Petugas Kesehatan

$\checkmark \quad$ Petugas Pelayanan Loket

$\checkmark \quad$ Ruang Pelayanan Informasi

$\checkmark$ Petugas Layanan Informasi

$\checkmark$ Petugas Parkir

$\checkmark$ Petugas Pengecek Tiket

$\checkmark$ Petugas Penitipan Barang

- Pengantar atau penjemput penumpang; dan

- Pelaku kegiatan komersial meliputi, karyawan pertokoan atau kios.

Setiap ruang di stasiun kereta api mempunyai fungsi tertentu sesuai dengan jenis aktivitas dan fasilitas pelayanan yang ditempatkan di ruang tersebut. Kebutuhan ruang-ruang yang didapatkan dari analisis alur kegiatan dari pelakupelaku kegiatan di atas dapat dilihat pada gambar berikut

\begin{tabular}{l|l|l} 
& Jalur Pedestrian & R. Parkir Pengelola \\
Main Entrance & R. Penerima \\
Pos Parkir & R. Serbaguna \\
Jalur Parkir Umum & R. Administrasi \\
Jalur Parkir VIP & R. Kepala Stasiun \\
R. ATM & R. Wakil Kepala Stasiun \\
R. PBD (Perbendaharaan)
\end{tabular}

d. Layout Ruang

Pola organisasi ruang yang paling cocok diterapkan untuk di Stasiun Kereta Api Kedundang berdasarkan analisis besaran, hubungan, bentuk dasar dan pola organisasi ruang yang disesuaikan terhadap bentuk tapak ialah pola linier. Pola linier merupakan ciri khas pola ruang pada bangunan stasiun kereta api yang ada di Indonesia. Kesimpulan dari analisis-analisis keruangan tersebut, maka didapatkan layout ruang sebagai berikut: 


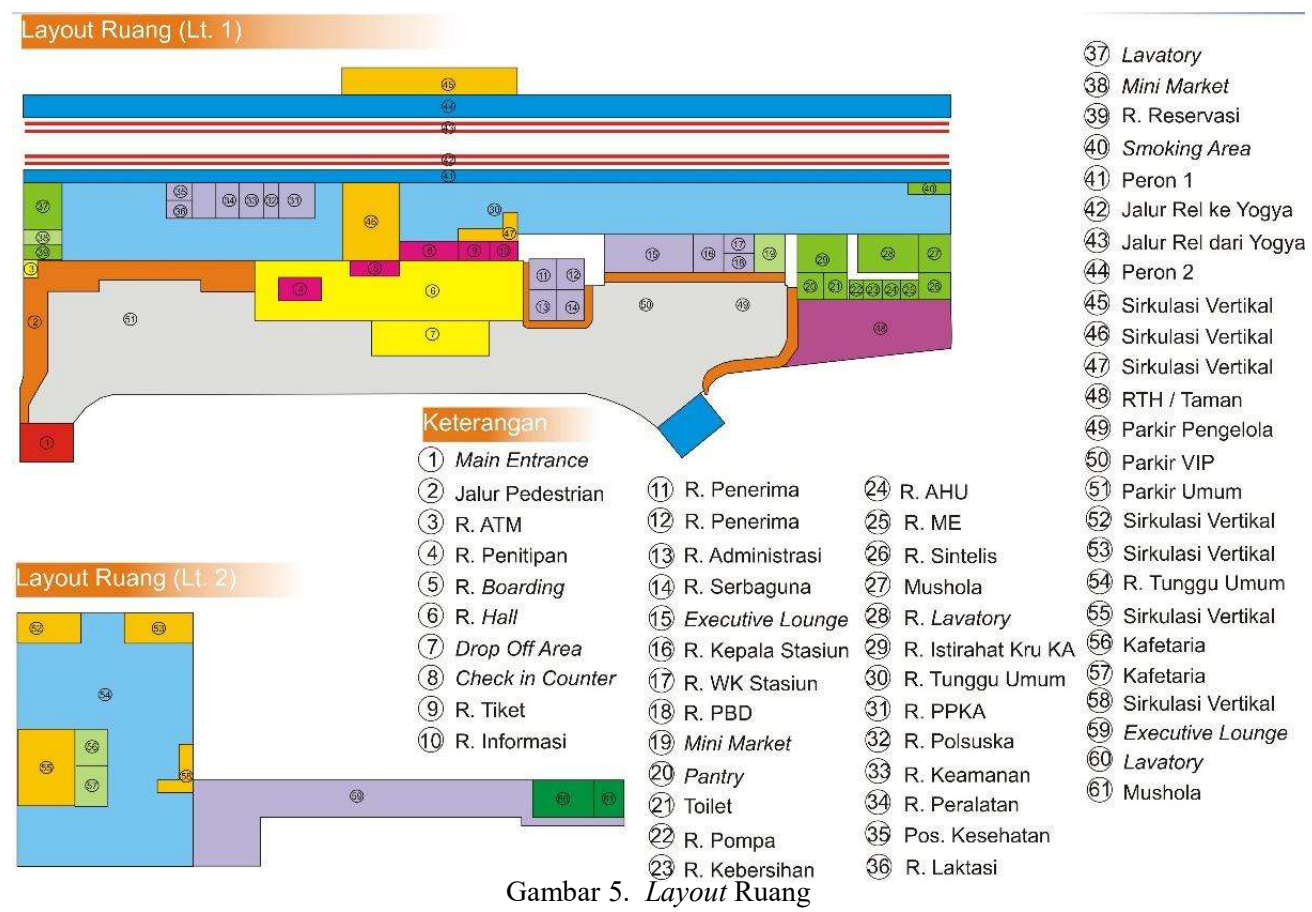

\section{e. Sirkulai antar Ruang}

Konsep sirkulasi antar ruang yang digunakan ialah pola linier dengan Ruang Tunggu Umum sebagai ruang bersama berada di tengah menjadi ruang yang menghubungkan jalan dan ruang-ruang lain. Ruang Tunggu Umum di lantai 2 (dua) berfungsi sebagai jembatan/ sirkulasi penghubung ke peron jalur 2 (dua) di sebelah utara, untuk menghindari perpotongan sirkulasi penumpang dengan kereta api.

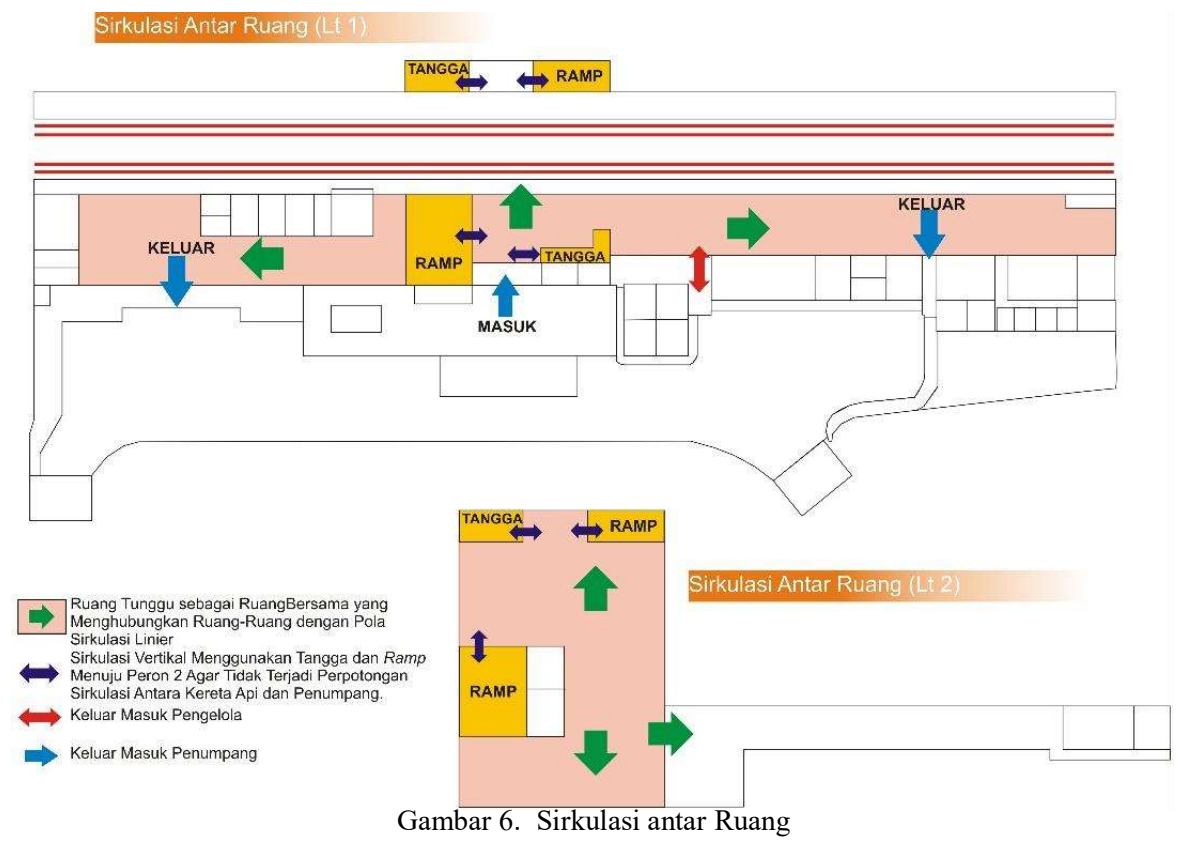




\section{f. Gubahan Massa}

Bentuk massa bangunan mempertimbangkan analisis organisasi ruang, elemen bentuk tapak, massa bangunan existing dan bentuk pola motif geblek renteng sebagai unsur yang mewakili lokalitas setempat.

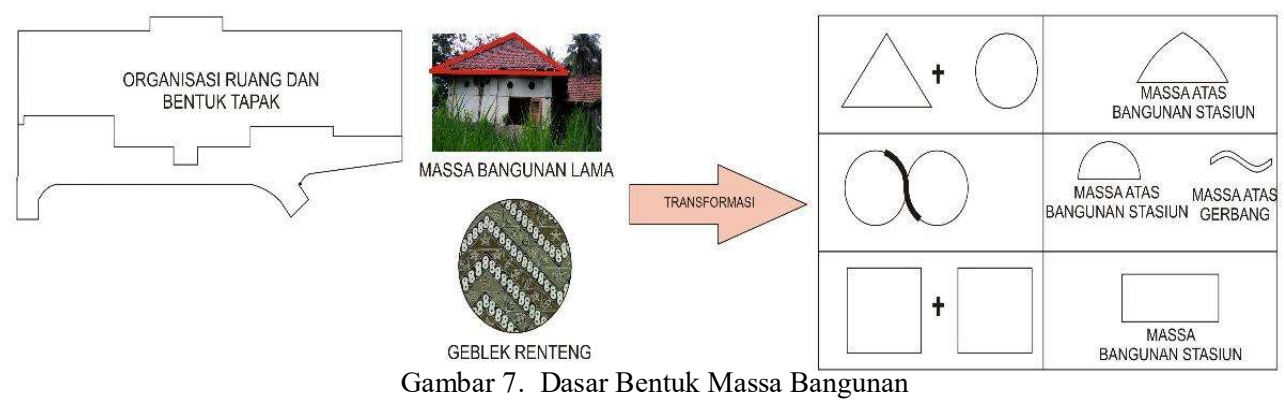

Hasil analisis elemen bentuk dasar massa bangunan didapatkan kombinasi bentuk dasar segitiga, persegi dan lingkaran yang menghasilkan bentuk-bentuk massa bangunan seperti pada gambar di bawah ini:
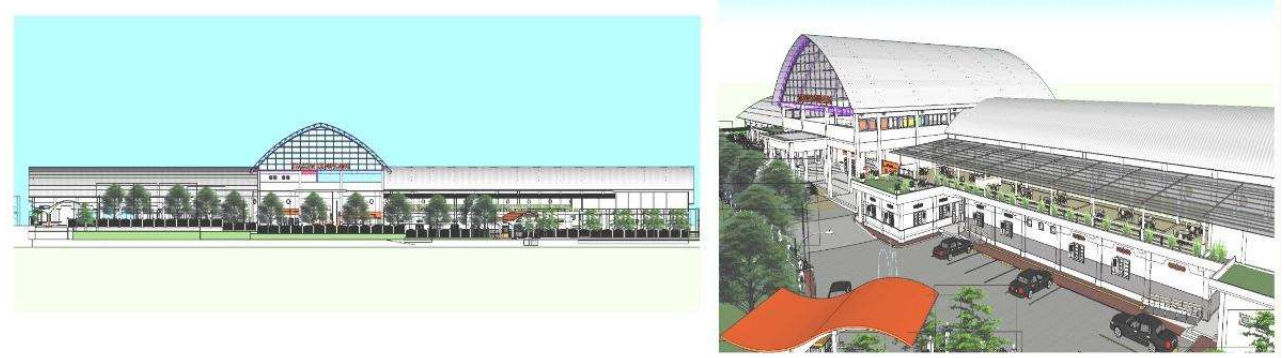

Gambar 8. Konsep Massa Bangunan

\section{g. Tata Ruang Luar}

Ruang luar adalah sebuah ruang yang terbentuk oleh batas horizontal bawah (bentang alam) dan batas vertikal (massa bangunan atau vegetasi) massa berupa bangunan atau vegetasi dan ruang luar yang terbentuk diantaranya, bersama-sama perlu disusun dan diintegrasikan dalam tapak untuk menciptakan sebuah lingkungan yang baik. Komponen-komponen ruang luar terdiri dari tata vegetasi, ruang jalur sirkulasi kendaraan dan pejalan kaki, pagar dan gerbang serta façade bangunan. Vegetasi berfungsi sebagai peneduh, pengarah sirkulasi, sekaligus pemecah angin. Pagar dan gerbang stasiun berfungsi sebagai pembatas tapak dan fungsi keamanan dalam lingkungan stasiun kereta api. Jalur kendaraan dan pejalan kaki dirancang sedemikian rupa agar setiap pengguna dapat bergerak bebas ke tujuannya tanpa adanya perpotongan jalur sirkulasi. 


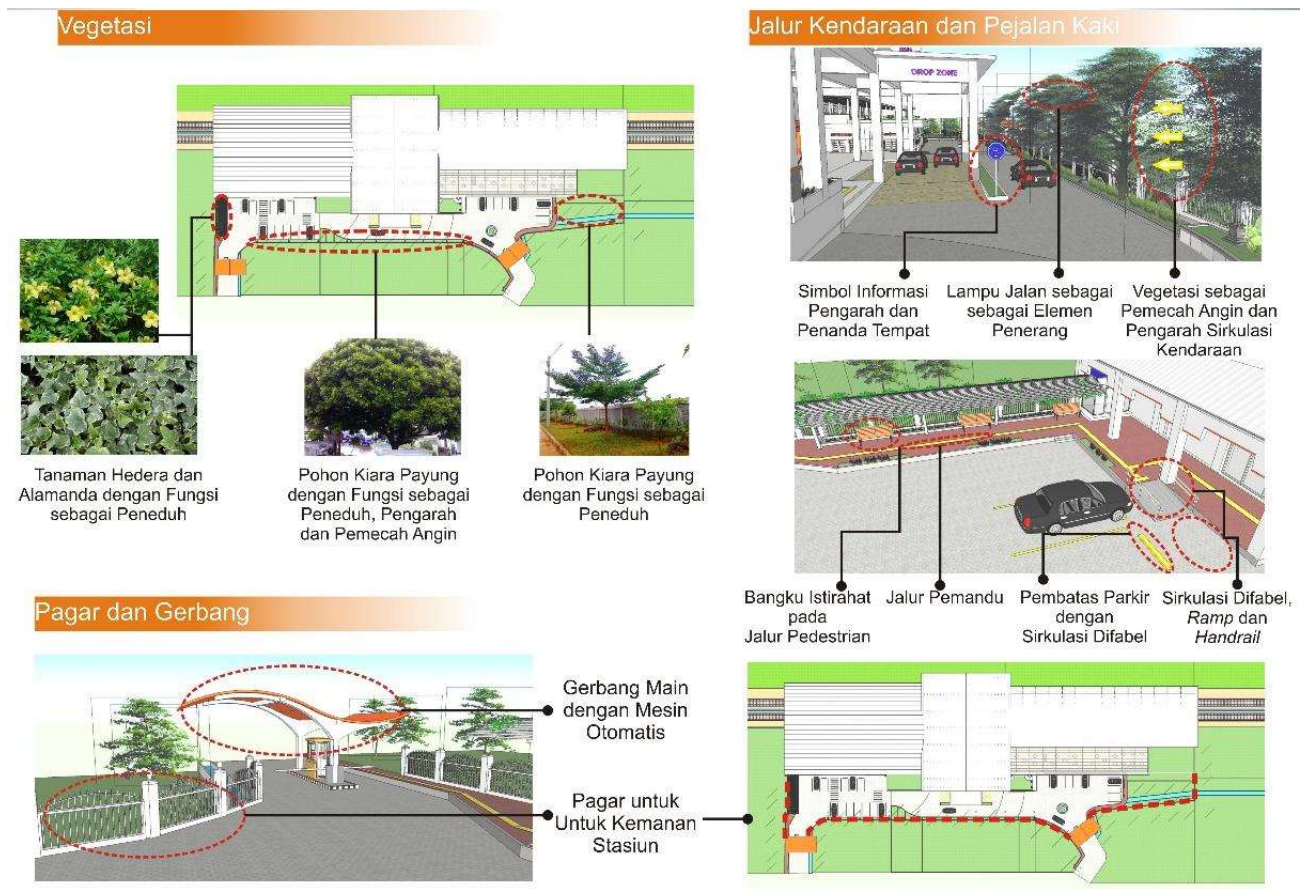

Gambar 9. Tata Ruang Luar

Konsep Façade yang digunakan pada bangunan mengkombinasikan antara elemen-elemen bentuk façade bangunan existing dengan bentuk-bentuk baru dengan tujuan agar tidak menghilangkan identitas Stasiun Kereta Api Kedundang sebagai stasiun kereta api yang memiliki nilai sejarah.

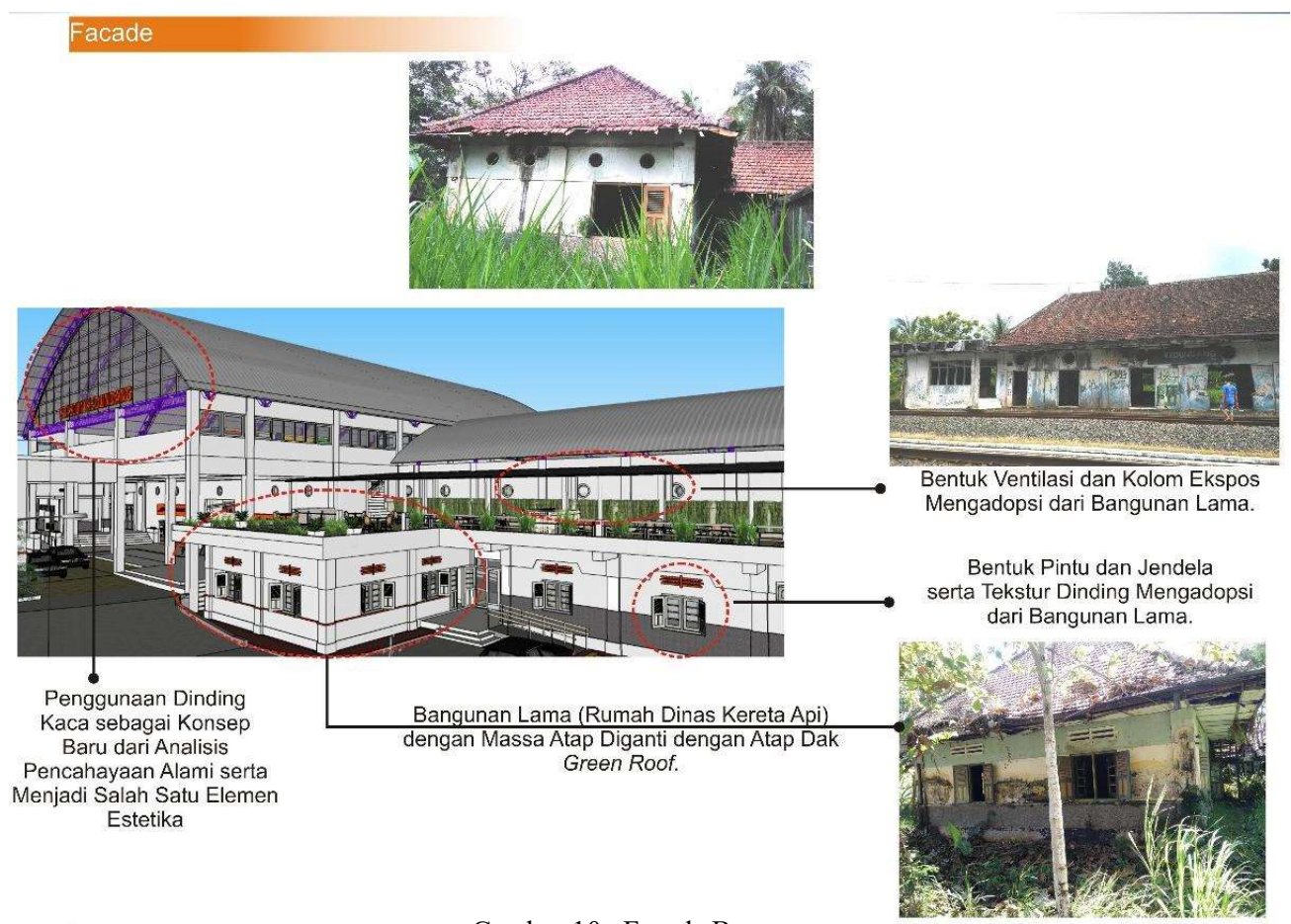

Gambar 10. Façade Bangunan 
h. Penghawaan dan Pencahayaan Alami

Penghawaan dan pencahyaan alami sangat penting dalam sebuah bangunan mengingat pentingnya penghematan energi dalam merancang bangunan, selain itu juga penghawaan dan pencahayaan alami dapat menjadi nilai estetika dan menciptakan kenyamanan ruang tersendiri di dalam bangunan.

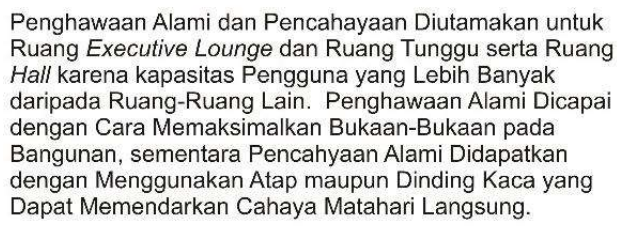

Penghawaan Alami dan Pencahayaan Diutamakan untuk Ruang Executive Lounge dan Ruang Tunggu serta Ruang Hall karena kapasitas Pengguna yang Lebih Banyak daripada Ruang-Ruang Lain. Penghawaan Alami Dicapai dengan Cara Memaksimalkan Bukaan-Bukaan pada Bangunan, sementara Pencahyaan Alami Didapatkan dengan Menggunakan Atap maupun Dinding Kaca yang Dapat Memendarkan Cahaya Matahari Langsung.
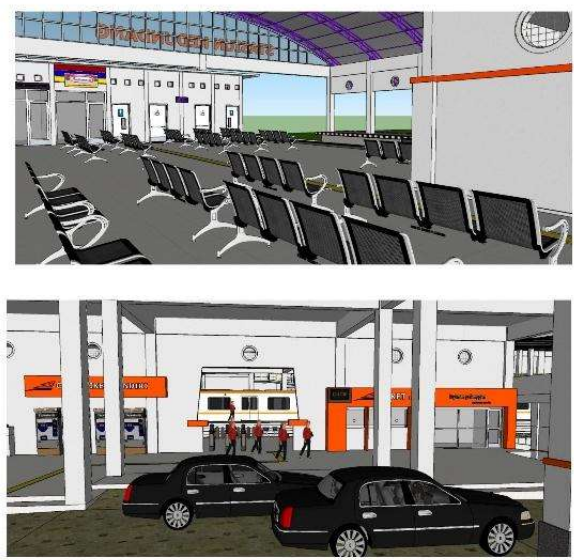

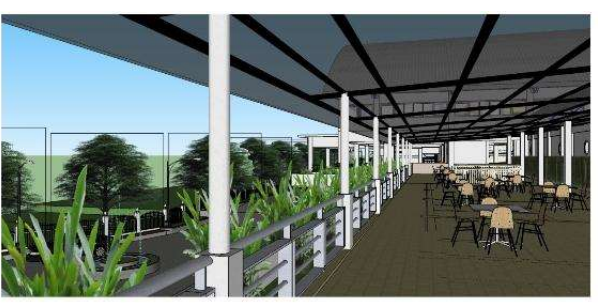

Executive Lounge

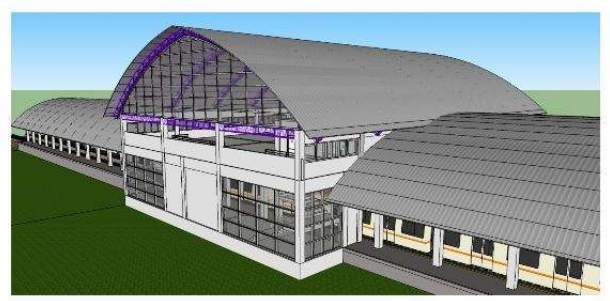

Dinding-Dinding Kaca yang Dapat Memendarkan Cahaya Matahari Langsung

Optimalisasi Bukaan Pada Ruang Tunggu Umum dan Hall

Gambar 11. Penghawaan dan Pencahayaan Alami

i. Ruang dan Sirkulasi Aksesibel

Aksesbilitas adalah kemudahan bagi seluruh pengguna termasuk difabel untuk mengakses fasilitas-fasilitas di dalam maupun di luar bangunan. Fasilitasfasilitas aksesibel antara lain tangga dengan kemiringan kurang dari 60 derajat serta ubin pengarah yang beguna untuk mengarahkan difabel untuk menuju tempattempat tujuannya terutama fasilitas-fasilitas umum. Kemudian fasilitas ramp bagi pejalan kaki di luar maupun di dalam bangunan. Ramp di luar bangunan dirancang dengan kemiringan maksimal 6 derajat dan dilengkapi dengan handrail, sedangkan ramp di dalam bangunan dirancang dengan kemiringan maksimal 7 derajat juga dilengkapi dengan handrail.

Peron menggunakan peron tinggi dengan material bertekstur kasar, garis batas aman dan ubin pemandu sehingga memudahkan semua pengguna naik turun dari kereta api. Selanjutnya di stasiun kereta api ini juga disediakan 6 unit toilet khusus untuk difabel masing-masing 3 (tiga) unit untuk pria dan wanita). 

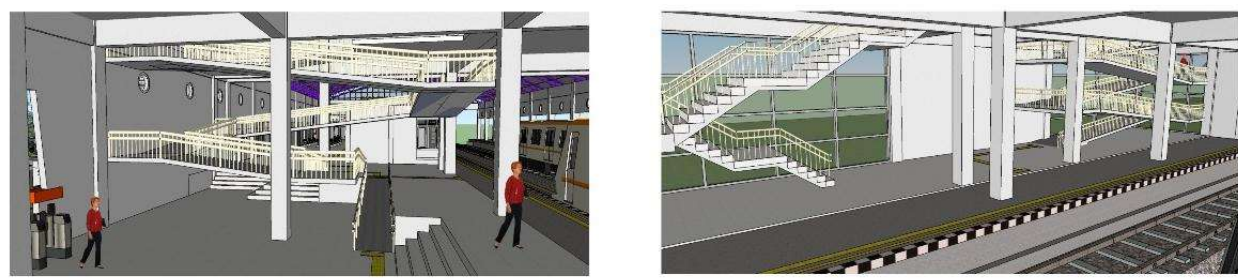

Tangga dengan kemiringan kurang dari 60 derajat dan Ramp dengan Kemiringan 7 derajat
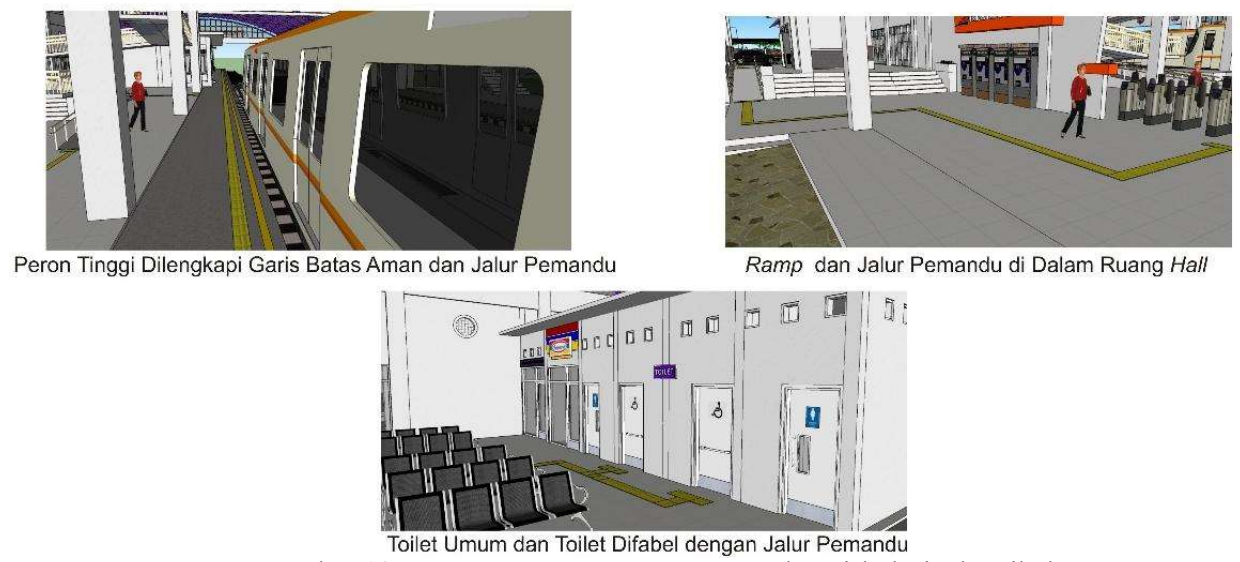

Gambar 12. Komponen-Komponen Ruang dan Sirkulasi Aksesibel

\section{Kesimpulan}

a. Revitalisasi dilakukan dengan menambahkan fasilitas-fasilitas ruang-ruang baru sesuai dengan Pedoman Standardisasi Stasiun Kereta Api Indonesia Tahun 2012 dan pemanfaatan bangunan lama dengan fungsi ruang baru untuk menyesuaikan terhadap kapasitas dan fungsi bandara baru.

b. Pola sirkulasi di dalam bangunan menggunakan pola linier, sedangkan di luar bangunan menggunakan pola tidak langsung. Pola sirkulasi dirancang dengan prinsip utama yaitu menghindari perpotongan antar jalur sirkulasi pejalan kaki dan kendaraan.

c. Pola tata ruang juga menggunakan pola yang sama yaitu pola linier yang merupakan ciri khas stasiun-stasiun kereta api di Indonesia. Hal ini dikarenakan menyesuaikan terhadap pola operasional kereta api dan alur kegiatan penumpang dari kedatangan hingga keberangkatan penumpang.

d. Pola Sirkulasi dan tata ruang yang sinkron dalam perancangan ini sudah memenuhi standar keselamatan, keamanan dan kelancaran serta kenyamanan bagi penumpang sehingga dapat memberikan kesempatan yang optimal bagi penumpang maupun pengelola untuk melakukan berbagai kegiatan.

e. Konsep Gubahan massa bangunan, tata ruang luar, penghawaan dan pencahayaan alami, serta prinsip desain aksesibel di dalam perancangan arsitektur ini menjadi elemen-elemen penting sehingga terciptanya sebuah konsep bangunan Stasiun Kereta Api Kedundang sebagai alternatif solusi desain 


\section{Saran}

a. Kajian lebih lanjut mengenai permasalahan-permasalahan Stasiun Kereta Api Kedundang dan alternatif pemecahannya dapat menggunakan metode yang lain sehingga hasilnya dapat lebih optimal.

b. Bagi PT. KAI (Persero) seyogyanya membenahi dan mengembangkan stasiunstasiun kereta api di Indonesia agar dapat memberikan pelayanan yang lebih optimal kepada publik.

c. Pengembangan transportasi kereta api sangat diperlukan untuk menjadikan angkutan rel sebagai solusi alternatif bagi keterbatasan angkutan jalan. Program-program pengembangan infrastruktur-infrastruktur transportasitransportasi terpadu ke depannya dapat menciptakan sistem transportasi yang menjangkau dan memenuhi kebutuhan transportasi publik.

\section{Daftar Pustaka}

Program Studi Arsitektur SAPPK ITB. 2006. Manual Desain Bangunan Aksesibel. Disusun dan Diringkas dari Berbagai Sumber oleh SAPPK ITB, Bandung.

Persyaratan Teknis Bangunan Stasiun Kereta Api. 2011. Peraturan Menteri Perhubungan Nomor: PM.29 Tahun 2011. Kementerian Perhubungan Republik Indonesia, Jakarta.

BPS Kabupaten Kulon Progo. 2017. Statistik Daerah Kabupaten Kulon Progo 2017. BPS Kabupaten Kulon Progo, Kulon Progo.

D.K. Ching, Francis. 2008. Arsitektur Bentuk, Ruang, dan Tatanan. Edisi Ketiga. Penerbit Erlangga, Yogyakarta.

Dinas Pertanahan dan Tata Ruang Kabupaten Kulon Progo. 2018. Rencana Tata Ruang (RTR) Kawasan Strategis Bandar Udara Tahun 2018-2038. Dinas Pertanahan dan Tata Ruang Kabupaten Kulon Progo, Kulon Progo.

Direktur Jenderal Perhubungan Darat. 1996. Pedoman Teknis Penyelenggaraan Fasilitas Parkir. Departemen Perhubungan Direktur Jenderal Perhubungan Darat, Jakarta.

Dwiatmoko, Hermanto. 2016. Perencanaan Pembangunan Transportasi Kereta Api. Edisi Pertama. Penerbit Kencana Prenada Media Group, Jakarta.

Jenis, Kelas dan Kegiatan di Stasiun Kereta Api. 2011. Peraturan Menteri Perhubungan Nomor: PM.33 Tahun 2011. Kementerian Perhubungan Republik 
Komite FAL Udara Yogyakarta. 2016. Laporan Rapat Koordinasi Nasional Komite FAL Udara Yogyakarta. FALNAS Kadishub Yogyakarta, Yogyakarta.

New Yogyakarta International Airport (NYIA). 2017. Paparan Tematik NYIA Asisten Ekobang. Asisten Perekonomian dan Pembangunan Setda DIY, Yogyakarta.

Pedoman Standardisasi Stasiun Kereta Api Indonesia. 2012. Keputusan Direksi PT. Kereta Api Indonesia (Persero) Nomor: Kep.U/LL.104/I/1/KA-2012. PT. Kereta Api Indonesia (Persero), Bandung. 